\title{
IMPLEMENTASI MANAJEMEN KEPALA SEKOLAH DALAM MEWUJUDKAN SEKOLAH ADIWIYATA DI SMK NEGERI 1 TEMBILAHAN
}

\author{
Henny Kirana ${ }^{1)}$ \\ Zulkarnaini ${ }^{2)}$ \\ Murni Baheraam 3) \\ ${ }^{1)}$ Post Graduate Student of Riau University \\ ${ }^{2)}$ Lecture of Education Management Study Programme PPs University of Riau \\ ${ }^{3)}$ Lecture of Education Management Study Programme PPs University of Riau
}

\section{ABSTRACT}

This research to describe the management Implementation of the principal in realizing the adiwiyata school in SMK Negeri 1 Tembilahan. This study is qualitative to the type of case study. Data collection is done through observation, interview and documentation study. The results showed that in realizing the adiwiyata program at SMK Negeri 1 Tembilahan, various management functions were applied by the principal. Starting from the planning, organizing, implementation and control performed by the principal, then with the hard work of the principal and all related elements can be realized adiwiyata program at SMK Negeri 1 Tembilahan.

Keywords: Implementation, Management, Principal, Adiwiyata

\begin{abstract}
ABSTRAK
Penelitian ini bertujuan untuk menganalisis implementasi manajemen kepala sekolah dalam mewujudkan sekolah adiwiyata di SMK Negeri 1 Tembilahan. Metode yang digunakan adalah pendekatan kualitatif dengan jenis penelitian study kasus. Pengumpulan data dilakukan melalui observasi, wawancara dan studi dokumentasi. Hasil penelitian menunjukkan bahwa dalam merealisasikan program adiwiyata di SMK Negeri 1 Tembilahan, berbagai fungsi manajemen diterapkan oleh kepala sekolah. Mulai dari perencanaan, pengorganisasian, implementasi dan pengawasan yang dilakukan oleh kepala sekolah, kemudian dengan kerja keras kepala sekolah dan semua elemen terkait untuk mewujudkan sekolah adiwiyata di SMK Negeri 1 Tembilahan.
\end{abstract}

Kata Kunci : Implementasi, Manajemen, Kepala Sekolah, Adiwiyata 


\section{PENDAHULUAN}

Program Adiwiyata merupakan salah satu program Kementrian Negara Lingkungan Hidup dalam rangka mendorong terciptanya pengetahuan dan kesadaran warga sekolah dalam upaya pelestarian lingkungan hidup. Program ini diharapkan setiap warga sekolah ikut terlibat dalam kegiatan sekolah menuju lingkungan yang sehat serta untuk menghindari dampak lingkunga yang negatif. Tujuan program adiwiyata adalah menciptakan kondisi sekolah yang baik untuk menjadi tempat pembelajaran penyadaran warga sekolah, sehingga kemudian hari warga sekolah tersebut dapat bertanggung jawab dalam upaya-upaya penyelamatan lingkungan hidup dan pembangunan berkelanjutan.

Seiiring dengan semakin kompleknya permasalahan lingkungan hidup menjadi hal penting dan mendesak untuk semakin menggencarkan kepedulian akan lingkungan yang berawal dari sekolah melalui program Adiwiyata sekolah untuk menumbuhkan kepedulian lingkangan dan membentuk karekter peserta didik untuk peduli lingkungan. Atas dasar tersebut, maka sekolah Adiwiyata memiliki manfaat yang sangat besar dan luas. Adapun manfaat dari sekolah Adiwiyata diantaranya;1).mendukung pencapaian standar kompetensi dasar dan kompetensi lulusan pendidikan dasar dan menengah, 2) meningkatkan efisiensi penggunaan dana operasional sekolah melalui penghematan dan pengurangan konsumsi berbagai sumber daya dan energi, 3) menciptakan kondisi belajar-mengajar yang nyaman dan kondusif bagi warga sekolah, 4) menjadikan tempat pembelajaran nilai-nilai Pendidikan Lingkungan Hidup yang baik dan benar bagi warga sekolah dan masyarakat sekitar, 5) meningkatkan upaya berkonsep Pendidikan Lingkungan Hidup melalui kegiatan pengendalian pencemaran dan pengendalian kerusakan lingkungan serta malalui kegiatan pelestarian fungsi lingkungan sekolah.

Menurut Warsono (2017: 222) program Adiwiyata bermuara pada implementasi Pendidikan untuk pembangunan berkelanjutan. Melalui paradigma program pembangunan berkelanjutan (suistainable development), penerapan undangundang lingkungan, penegakan hukum, dan upaya perlindungan dan pengelolaan lingkungan terus dilakukan oleh pemerintah dan masyarakat. Hal ini termasuk melalui jalur pendidikan lingkungan hidup. Berdasarkan data Deputi Bidang Komunikasi Lingkungan dan Pemberdayaan Masyarakat Kementrian Lingkungan Hidup, upaya mempercepat pelaksanaan program pembangunan berwawasan lingkungan melalui jalur pendidikan telah dilakukan pemerintah. Untuk meningkatkan peran pemerintah dalam memecahkan persoalan lingkungan melalui jalur pendidikan, Departemen Pendidikan Nasional dan KementrianLi ngkungan Hidup mengembangkan program PLH pada jenjang pendidikan dasar dan menengah melalui Adiwiyata.

$$
\text { Penyelenggaraan sekolah }
$$

Adiwiyata merupakan pilihan dan upaya strategis dalam mensukseskan program pembangunan nasional berkelanjutan. Melalui penyelenggaraan model sekolah inilah akan terbangun komitmen, kesadaran dan tanggung jawab antara warga sekolah, komite sekolah, forum orang tua, dan berbagai pihak yang terlibat di dalam lingkungan sekolah (stakeholder) untuk berpartisipasi aktif menjaga, memelihara dan melestarikan lingkungan. Sebagai sebuah lembaga, 
sekolah Adiwiyata diharapkan mampu menjadi media tepat dan ideal untuk mendidik dan menanamkan budaya positif dan strategis dalam mengubah pola pikir masyarakat dalam melindungi dan mengelola lingkungan hidup.

Program Adiwiyata memiliki beberapa komponen. Komponenkomponen tersebut mendukung terlaksananya sekolah yang peduli dan berwawasan lingkungan. Menurut Peraturan Menteri Lingkungan Hidup Republik Indonesia Nomor 05 Tahun 2013 Pasal 6 Ayat 1 tentang Pedoman Pelaksanaan Program Adiwiyata, meliputi: (a) Aspek Kebijakan sekolah berwawasan lingkungan; (b) Aspek kurikulum berwawasan lingkungan; (c) Aspek kegiatan sekolah berbasis partisipatif; dan (d) Aspek pengelolaan sarana dan prasarana pendukung sekolah yang ramah lingkungan.

Sekolah Adiwiyata dalam pegembangan kurikulum yang terintegrasi dengan Pendidikan Lingkungan Hidup (PLH) terhadap pembelajaran formal di sekolah. Menurut Kementrian Negara Lingkungan Hidup (2007), pendidikan lingkungan hidup adalah upaya mengubah perilaku dan sikap yang dilakukan oleh berbagai pihak atau elemen masyarakat yang bertujuan meningkatkanpengetahuan keterampilan dan kesadaran masyarakat tentang nilainilai lingkungan dan isu permasalahan lingkungan yang pada akhirnya dapat menggerakkan masyarakat untuk berperan aktif dalam upaya pelestarian dan keselamatan lingkungan untuk kepentingan generasi sekarang dan yang akan datang. Pendidikan lingkungan hidup juga mencakup praktik dalam pengambilan keputusan dan perumusan karakter diri tentang isu-isu mengenai kualitas lingkungan.

Untuk mencapai tujuan program
Adiwiyata, maka ditetapkan empat komponen program yang menjadi satu kesatuan utuh dalam mencapai sekolah Adiwiyata. Keempat komponen tersebut adalah 1) Kebijakan Berwawasan Lingkungan, 2)Pelaksanaan Kurikulum Berbasis Lingkungan, 3) Kegiatan Lingkungan Berbasis Partisipatif 4) Pengelolaan Sarana Pendukung Ramah Lingkungan. Beragam keuntungan yang di dapatkan oleh warga sekolah jika mengikuti program adiwiyata, antara lain; 1) Mendukung pencapaian standar kompetensi inti/kompertensi dasar dan standar kompetensi lulusan (SKL) pendidikan dasar dan menengah, 2). Meningkatkan efesiensi penggunaan dana operasional sekolah melalui penghematan dan pengurangan konsumsi dari berbagai sumber daya dan energi, 3). Menciptakan kebersamaan warga sekolah dan kondisi belajar mengajar yang lebih nyaman dan kondusif, 4). Menjadi tempat pembelajaran tentang nilai-nilai pemeliharaan dan pengelolaan lingkungan hidup yang baik dan benar bagi warga sekolah dan masyarakat sekitar, 5). Meningkatkan upaya perlindungan dan pengelolaan lingkungan hidup meIalui kegiatan pengendalian pencemaran, pengendalian kerusakan dan pelestarian fungsi lingkungan di sekolah.

Tujuan program adiwiyata di SMK Negeri 1 Tembilahan adalah untuk mewujudkan warga sekolah yang bertanggung jawab dalam upaya perlindungan dan pengelolaan lingkungan hidup melalui tata kelola sekolah yang baik, indah, asri dan bersih untuk mendukung pembangunan yang berkelanjutan. Dengan melaksanakan program adiwiyata di harapkan akan menciptakan warga sekolah, khususnya peserta didik yang peduli dan berbudaya lingkungan, sekaligus mendukung dan mewujudkan 
sumberdaya manusia yang memiliki karakter bangsa terhadap perkembangan ekonomi, sosial, dan lingkungannya dalam mencapai pembangunan berkelanjutan di daerah, serta sebagai realisasi dari visi sekolah yaitu: menjadi lembaga pendidikan bisnis tingkat menengah yang unggul sebagai pendorong dan penggerak bidang kejuruan untuk menghasilkan SDM yang berkualitas, berbudaya lingkungan dan kepribadian dalam menghadapi persaingan era global.

Untuk mencapai tujuan yang diharapkan, dibutuhkan organisasi di dalamnya terdapat organization cooperation atau kerjasama organisasi yang memerlukan manajemen agar pencapaian tujuan akan lebih efektif dan efisien. Gunawan (2017:27) menyebutkan bahwa manajemen merupakan proses perencanaan, pengorganisasian, pelaksanaan dan pengawasan untuk optimalisasi penggunaan sumber-sumber dan pelaksanaan tugas-tugas dalam mencapai tujuan-tujuan organisasi secara efektif dan efisien.

Manajemen mempunyai empat fungsi, yaitu perencanaan (planning), pengorganisasian (organizing), pelaksanaan (actuating), pengawasan (controlling). Dari keempat fungsi dasar manajemen tersebut selanjutnya dapat dilakukan tindak lanjut setelah diketahui bahwa tujuan yang telah ditetapkan "tercapai" atau "belum" tercapai. Manajemen kepala sekolah dapat diartikan sebagai segala sesuatu yang berkenaan dengan pengelolaan dalam mencapai suatu tujuan dalam hal ini adalah mewujudkan sekolah Adiwiyata.

\section{KAJIAN TEORETIS}

\section{Implementasi}

Pengertian Implementasi menurut kamus besar bahasa Indonesia (KBBI) yaitu pelaksanaan atau juga penerapan. Pelaksanaan ataupun penerapan yang bertujuan untuk mencari bentuk tentang hal yang telah disepakati. Pressman dan Wildvsky dalam Erwan (2012:20) mendefenisikan implementasi adalah tindakan untuk melaksanakan, memenuhi dan meneyelesaikan sebuah kewajiban maupun kebijakan yang sudah di rancang. Sedangkan Usman berpendapat, implementasi adalah sebuah muara dimana terjadi aksi, tidakan maupun aktivitas yang dilakukan secara sistematis dan terikat oleh mekanisme. Implementasi juga diartikan sebagai sebuah kegiatan yang sudah direncanakan guna mencapai tujuan dari kegiatan tersebut.

Dalam kontek kebijakan publik yang dilaksanakan oleh pihak berwenang seperti pejabat dalam hal ini adalah kepala sekolah, Prof. $\mathrm{H}$. Tachjan memberikan defenisi implementasi adalah sebuah proses dari kegiatan administrasi yang mana dilakukan setelah sebuah kebijakan tertentu dibuat ataupun disetujui. Implementasi dikenal dengan makna suatu penerapan. Menurut Nugroho (2004:158), implentasi kebijakan pada prinsipnya adalah cara agar sebuah kebijakan dapat mencapai tujuannya. Tidak lebih dan tidak kurang. Untuk mengimplementasi kebijakan publik, maka ada dua pilihan langkah yang ada, yaitu langsung mengimplementasi dalam bentuk program-program atau melalui formulasi kebijakan derivat atau turunan dari kebijakan publik tersebut. Menurut Daniel (2006:139). Implementasi kebijakan adalah pelaksanaan keputusan kebijaksanaan dasar, biasanya dalam bentuk undangundang, namun dapat pula berbentuk perintah-perintah atau keputusankeputusan eksekutif yang penting atau 
keputusan badan peradilan. Lazimnya, keputusan tersebut mengidentifikasi masalah yang ingin diatasi, menyebutkan secara tegas tujuan atau sasaran yang ingin dicapai, dan berbagai cara untuk menstrukturkan atau mengatur proses implementasinya.

\section{Manajemen Kepala Sekolah}

Manajemen merupakan alat untuk mencapai suatu tujuan yang di tentukan. Manajemen yang baik akan memudahkan terwujudnya tujuan suatu organisasi baik perusahan, sekolah dan masyarakat. Manajemen berasal dari kata manage yang berarti mengurus, memimpin, mencapai, dan memerintah. Manajemen berasal dari bahasa Latin, yaitu manus yang artina tangan dan agree yang artinya melakukan. Dua kata tersebut digabung menjadi managere, yang berarti menangani, melakukan dengan tangan. Usman (2009:5) mengemukakan managere diterjemahkan kedalam Bahasa Inggris, dalam bentuk kata kerja to manage, kata benda management, dan manager untuk orang yang melakukan kegiatan manajemen. Menurut Malayu dalam Gunawan (2017:22) mengatakan bahwa manajemen adalah suatu proses yang terdiri dari tindakantindakan perencanaan, pengorganisasian, menggerakkan dan mengendalikan, yang dilakukan untuk menentukan serta mencapai sasaran yang telah ditentukan melalui pemanfaatan sumber daya manusia dan sumber daya lainnya. Sedangkan menurut Pidarta (1988:4), manajemen ialah proses mengintegrasikan sumber- sumber yang tidak berhubungan menjadi sistem total untuk menyelesaikan suatu tujuan, yang dimaksud sumber disini ialah mencakup orang orang, alat-alat media, bahan-bahan, uang dan sarana. Semuanya diarahkan dan dikoordinasi agar terpusat dalam rangka menyelesaikan tujuan.

Menurut Gunawan (2017:29)

Manajemen pendidikan adalah suatu proses keseluruhan semua kegiatan bersama dalam bidang pendidikan dengan memanfaatkan semua fasilitas yang tersedia, baik personil, material, maupun spiritual untuk mencapai tujuan pendidikan. Sekolah dengan berbagai aktivitas dan kegiatannya dalam rangka mencapai tujuan pendidikan sekolah, memerlukan manajemen yang andal.

Tujuan manajemen pendidikan erat sekali dengan tujuan pendidikan secara umum, karena manajemen pendidikan pada hakekatnya merupakan alat untuk mencapai tujuan pendidikan secara optimal. Apabila dikaitkan dengan pengertian manajemen pendidikan pada hakekatnya merupakan alat mencapai tujuan. Adapun tujuan pendidikan nasionalyaitu untuk mengembangkannya potensi peserta didik agar menjadi manusia yang beriman dan bertaqwa kepada tuhan yang maha esa, berakhlak mulia, sehat, berilmu, cakap, kreatif, mandiri, dan menjadi warga Negara yang demokratis serta bertanggung jawab. Dalam UU Sisdiknas No. 20 Tahun 2003, tujuan pokok memperlajari manajemen pendidikan adalah untuk memperoleh cara,tehnik, metode yang sebaik-baiknya dilakukan, sehingga sumber-sumber. Yang sangat terbatas seperti tenaga, dana, fasilitas, material maupun sepiritual guna mencapai tujuan pendidikan secara efektif dan efisien.

Manajemen sebagai suatu proses yang telah ditetapkan tentunya manajemen mempunyai suatu langkah yang sistemik dan sistematik dalam mencapai suatu tujuan yang 
ingin dicapai. Dalam arti yang lebih luas manajemen juga bisa disebut sebagai pengelolaan sumber-sumber daya guna mencapai suatu tujuan yang telah ditetapkan, karenanya manajemen ini memegang peranan yang sangat penting dalam dunia pendidikan. Dalam proses manajemen terdapat fungsi- fungsi manajemen, diantaranya yaitu: 1) Perencanaan (planning) perencanaan adalah proses mendefenisikan tujuan organisasi, membuat strategi untuk mencapai tujuan tersebut, dan mengembangkan rencana aktivitas kerja organisasi. Perencanaan merupakan hal terpenting dari semua proses manajemen, karena tanpa perencanaan, proses manajemen lain yakni pengorganisasian, penggerakkan dan pengawasan, tidak dapat berjalan.

2) Pengorganisasian (organizing), Menurut Fattah (2017:56) dalam gunawan pengorganisasian adalah bagaimana pekerjaan diatur dan dialokasikan diantara para naggota, sehingga tujuan organisasi dapat tercapai secara efektif dan efisien. Pengorganisasian adalah penataan skumpulan tugas kedalam unit-unit yang dapat dikelola dan penetapan hubungan formal di antara orangorang yang diserahi berbagai tugas untuk mencapai tujuan organisasi, 3). Pelaksanaan (actuating) Pelaksanaan didefenisikan sebagai keseluruhan usaha, cara, teknik, dan metode untuk mendorong para anggota organisasi agar mau dan ikhlas bekerja sebaik mungkin demi terciptanya tujuan organisasi dengan efektif, efisien, dan ekonomis. Kepala sekolah sebagai manajer sekolah, harus mampu melaksanakan fungsi pergerakkan. 4).Pengawasan (controlling) Pengawasan adalah proses dalam menetapkan ukuran kinerja dan pengambilan tindakan yang dapat mendukung pencapaian hasil yang diharapkan sesuaidengan kinerja yang telah ditetapkan tersebut. Herujito dalam gunawan (2017:88) pengawasan (controlling) adalah mengamati dan mengalokasikan dengan penyimpangan yang terjadi. Pengawasan merupakan fungsi yang menjamin bahwa kegiatan-kegiatan dapat memberikan hasil seperti yang diinginkan.

Gunawan menyatakan kepala sekolah sebagai Manager melakukan perencanaan, pengorganisasian, pengerakkan dan pengawasan seluruh program sekolah, termasuk didalammya mewujudkan program adiwiyata. Kepala Sekolah adalah seorang yang sangat bertanggung jawab dalam meningkatkan mutu lembaga yang dipimpinnya. Sebagai Orang yang sangat bertanggung- jawab dalam perkembangan maju atau mundurnya lembaga yang dia pimpin, maka seorang pemimpin harus memiliki sifat-sifat yang dapat diterima dan disenangi oleh orang yang dipimpinnya. Kalau seorang Kepala Sekolah itu sudah disenangi oleh semua warga atau seluruh komponen yang terkait di Sekolah tersebut.

Mulyasa

(2017:22-45)

Kepemimpinan kepala sekolah berkaitan dengan berbagai tugas dan fungsi yang harus diembannya dalam mewujudkan sekolah efektif, produktif, mandiri dan akuntabel. Dari berbagai tugas dan fungsi kepala sekolah yang harus diembannya dalam mewujudkan program sekolah maka terdapat sepuluh kunci sukses kepemimpinan kepala sekolah tersebut mencakup (1) visi yang utuh, (2) tanggung jawab, (3) keteladanan, 
(4) memberikan layanan terbaik, (5) mengembangkan orang, (6) membina rasa persatuan dan kesatuan, (7) fokus pada peserta didik, (8) manajemen yang mengutamakan praktik, (9) menyesuaikan gaya kepemimpinan, dan (10) memanfaatkan kekuasaan keahlian. Sehubungan dengan yang demikian maka Kepala Sekolah perlu memperhatikan beberapa hal dalam mengelola pendidikan untuk peningkatan dan pengembangan Sekolah yaitu sifat- sifat yang dapat menunjang keberhasilan dalam mempengaruhi guru-guru bawahan lainnya. Ada beberapa sifat yang diperlukan dalam kepemimpinan pendidikan Soetopo dan Soemanto dalam mulyasa (2017:43), yaitu: (1) rendah hati dan sederhana, bersifat suka menolong, (3) sabar dan memiliki kestabilan emosi, percaya kepada diri sendiri, (5) Jujur, adil dan dapat dipercaya,

keahlian dalam jabatan .

Menurut Keputusan Menteri Pendidikan dan Kebudayaan No. 026 Tahun 1996 Kepala Sekolah adalah guru yang memperoleh tambahan tugas untuk memimpin penyelenggaraan pendidikan dan upaya peningkatan mutu pendidikan sekolah. Kepala sekolah selain memimpin penyelenggaraan pendidikan di sekolah juga berperan/berfungsi sebagai pendidik, manajer, administrator, supervisor, pemimpin, pembaru dan pembangkit minat. Kepala sekolah merupakan seorang pemimpin di sekolahnya. Kepala sekolah harus dapat memainkan perannya sebagai pemimpin untuk menggerakkan semua warga sekolah dalam rangka mencapai tujuan pendidikan sekolah. Sehingga kepemimpinan kepala sekolah yang efektif sangat diperlukan untuk menopang keberhasilan dengan kinerja yang telah ditetapkan tersebut. Herujito dalam gunawan (2017:88) pengawasan (controlling) adalah mengamati dan mengalokasikan dengan penyimpangan yang terjadi. Pengawasan merupakan fungsi yang menjamin bahwa kegiatan-kegiatan dapat memberikan hasil seperti yang diinginkan. Gunawan (2017:574) menyatakan kepala sekolah sebagai Manager melakukan perencanaan, pengorganisasian, pengerakkan dan pengawasan seluruh program sekolah, termasuk didalammya mewujudkan program adiwiyata. Kepala Sekolah adalah seorang yang sangat bertanggung jawab dalam meningkatkan mutu lembaga yang dipimpinnya. Sebagai Orang yang sangat bertanggung- jawab dalam perkembangan maju atau mundurnya lembaga yang dia pimpin, maka seorang pemimpin harus memiliki sifat-sifat yang dapat diterima dan disenangi oleh orang yang dipimpinnya. Kalau seorang Kepala Sekolah itu sudah disenangi oleh semua warga atau seluruh komponen yang terkait di Sekolah tersebut.

$$
\text { Mulyasa }
$$

(2017:22-45)

Kepemimpinan kepala sekolah berkaitan dengan berbagai tugas dan fungsi yang harus diembannya dalam mewujudkan sekolah efektif, produktif, mandiri dan akuntabel. Dari berbagai tugas dan fungsi kepala sekolah yang harus diembannya dalam mewujudkan program sekolah maka terdapat sepuluh kunci sukses kepemimpinan kepala sekolah tersebut mencakup (1) visi yang utuh, (2) tanggung jawab, (3) keteladanan, (4) memberikan layanan terbaik, (5) mengembangkan orang, (6) membina rasa persatuan dan kesatuan, (7) fokus pada peserta didik, 
manajemen yang mengutamakan praktik, (9) menyesuaikan gaya kepemimpinan, dan (10) memanfaatkan kekuasaan keahlian. Sehubungan dengan yang demikian maka Kepala Sekolah perlu memperhatikan beberapa hal dalam mengelola pendidikan untuk peningkatan dan pengembangan Sekolah yaitu sifat- sifat yang dapat menunjang keberhasilan dalam mempengaruhi guru-guru bawahan lainnya. Ada beberapa sifat yang diperlukan dalam kepemimpinan pendidikan Soetopo dan Soemanto dalam mulyasa (2017:43), yaitu: (1) rendah hati dan sederhana, (2) bersifat suka menolong, (3) sabar dan memiliki kestabilan emosi, percaya kepada diri sendiri, (5) Jujur, adil dan dapat dipercaya, (6) keahlian dalam jabatan .

Menurut Keputusan Menteri Pendidikan dan Kebudayaan No. 026 Tahun 1996 Kepala Sekolah adalah guru yang memperoleh tambahan tugas untuk memimpin penyelenggaraan pendidikan dan upaya peningkatan mutu pendidikan sekolah. Kepala sekolah selain memimpin penyelenggaraan pendidikan di sekolah juga berperan/berfungsi sebagai pendidik, manajer, administrator, supervisor, pemimpin, pembaru dan pembangkit minat. Kepala sekolah merupakan seorang pemimpin di sekolahnya. Kepala sekolah harus dapat memainkan perannya sebagai pemimpin untuk menggerakkan semua warga sekolah dalam rangka mencapai tujuan pendidikan sekolah. Sehingga kepemimpinan kepala sekolah yang efektif sangat diperlukan untuk menopang keberhasilanpelaksanaan program sekolah yang efektif pula. Kepemimpinan kepala sekolah merupakan kunci keberhasilan sekolah.

3. Adiwiyata

Makna yang terkandung dari Sekolah Peduli dan Berbudaya Lingkungan atau Sekolah Berbudaya Lingkungan dan lebih dikenal sebagai Sekolah Adiwiyata. Adiwiyata mempunyai pengertian atau makna sebagai tempat yang baik, agung dan ideal dimana dapat diperoleh segala ilmu pengetahuan dan berbagai norma serta etika dalam kehidupan sosial yang dapat menjadi dasar manusia menuju terciptanya kesejahteraan hidup dan menuju kepada cita-cita pembangunan berkelanjutan.

Berdasarkan Peraturan Menteri Lingkungan Hidup No. 05/2013 , didefenisikan Adiwiyata adalah sekolah yang baik dan ideal sebagai tempat memperoleh segala ilmu pengetahuan dan berbagai norma serta etika yang dapat menjadi dasar manusia menuju terciptanya kesejahteraan hidup dan cita-cita pembangunan berkelanjutan. Menurut Ketut Prastyo (2017:221) Adiwiyata merupakan wahana bagi ESD (Education for Suistainable Development), yang berada dibawah koordinasi dan tanggung jawab Kementrian Negara Lingkungan Hidup. Program Adiwiyata adalah program untuk mewujudkan sekolah yang peduli dan berbudaya lingkungan, salah satu program kerja berlingkup nasional yang dikelola oleh Kementrian Negara Lingkungan Hidup dalam rangka mewujudkan pengembangan pendidikan lingkungan hidup.

Tim Adiwiyata tingkat nasional (2012:3) mengungkapkan bahwa tujuan Adiwiyata adalah mewujudkan warga sekolah yang bertanggung jawab dalam upaya perlindungan dan pengetahuan lingkungan hidup melalui tata kelola sekolah yang baik 
untuk mendukung pembangunan yang berkelanjutan. Untuk mewujudkan tujuan tersebut maka pelaksanaan program adiwiyata diatur prinsipprinsip dasar program adiwiyata. Prinsip-prinsip tersebut, antara lain; (1) partisipatif yaitu komunitas sekolah terlibat dalam manajemen sekolah yang meliputi keseluruhan proses perencanaan, pelaksanaan dan evaluasi sesuai tanggung jawab dan peran, (2) berkelanjutan yaitu seluruh kegiatan harus dilakukan secara terencana dan terus menerus secara komprehensif.

Kegiatan utama diarahkan pada terwujudnya kelembagaan sekolah yang peduli dan berbudaya lingkungan. Dengan mengembangkan norma-norma dasar yaitu norma kebersamaan, keterbukaan, kesetaraan, kejujuran, keadilan, dan kelestarian fungsi lingkungan hidup dan sumber daya alam. Berikut ini prinsip dasar yang melandasi pelaksanaan Adiwiyata.

Partisipatif, artinya semua bagian manajemen sekolah terlibat didalam seluruh proses perencanaan, persiapan, pelaksanaan dan penilaian sesuai tanggung jawab dan perannya. b) Berkelanjutan, artinya seluruh kegiatan harus dilakukan secara terencana dan terus-menerus dalam kurun waktu jangka panjang dan menyeluruh, meliputi aspek kehidupan dalam perencanaan, persiapan, pelaksanaan dan evaluasi sehingga dapat memberikan kontribusi yang besar bagi lingkungan (Ilyas Assad, 2011). Program Adiwiyata adalah program pengelolaan lingkungan hidup di sekolah. Program ini merupakan tindak lanjut dari Kesepakatan Bersama antara Menteri Negara Lingkungan Hidup dengan Menteri Pendidikan Nasional Nomor
Kep.07/MENLH/06/2005 dan Nomor 05/VI/KB/2005 tentang Pembinaan dan Pengembangan Lingkungan Hidup. Adiwiyata mempunyai pengertian atau makna: tempat yang baik dan ideal tempat diperolehnya segala ilmu pengetahuan dan berbagai norma serta etika yang dapat menjadi dasar manusia menuju terciptanya kesejahteraan hidup dan menuju kepada cita-cita pembangunan berkelanjutan. Sekolah adiwiyata adalah salah satu program Kementerian Lingkungan Hidup dalam rangka mendorong terciptanya pengetahuan dan kesadaran warga sekolah dalam upaya pelestarian lingkungan hidup. Atau Sekolah Adiwiyata adalah sekolah yang mempunyai lingkungan hidup dan melakukan pengelolaan lingkungan hidup di sekolah itu sendiri. Pelaksanaan Program Adiwiyata diletakkan pada dua prinsip dasar berikut: (1). Partisipatif: Komunitas sekolah terlibat dalam manajemen sekolah yang meliputi keseluruhan proses perencanaan, pelaksanaan dan evaluasi sesuai tanggungjawab dan peran. (2). Berkelanjutan: Seluruh kegiatan harus dilakukan secara terencana dan terus menerus secara komprehensif.

\section{METODOLOGI PENELITIAN}

Penelitian ini bertujuan untuk mendapatkan gambaran dan informasi yang lebih jelas, lengkap serta memungkinkan dan mudah bagi penulis untuk melakukan penelitian observasi. Oleh karena itu, maka penulis menetapkan lokasi penelitian adalah tempat dimana penelitian akan dilakukan. Dalam hal ini Tempat penelitian ini mengambil lokasi di Sekolah Menengah Kejuruan atau SMK Negeri 1 Tembilahan yang beralamat di jalan Baharuddin Yusuf 
Tembilahan, kelurahan Sungai Beringin, Kecamatan Tembilahan Kabupaten Indragiri Hilir. Penulis melakukan penelitian di SMK Negeri 1 Tembilahan untuk mengamati fenomena yang terjadi pada sekolah tersebut yang berkaitan dengan implementasi manajemen kepala sekolah dalam mewujudkan sekolah adiwiyata.

Metode penelitian yang digunakan pada penelitian ini menggunakan penelitian studi kasus, yaitu metode penelitian yang memfokuskan pada satu fenomena yang dipilih. Hai ini senada dengan yang dikemukakan oleh Sukmadinata (2011:99) bahwa penelitian studi kasus merupakan penelitian yang memfokuskan pada satu fenomena saja yang dipilih dan ingin dipahami secara mendalam, dengan mengabaikan fenomena lainnya dan fenomena tersebut bisa berupa seorang pemimpin, sekelompok siswa, suatu program, suatu proses, suatu penerapan kebiajakan atau suatukonsep.

Al Muchtar (2014:431)

mengatakan bahwa studi kasus merupakan suatu peristiwa atau kejadian dalam masyarakat, yang sangat menarik perhatian karena memuat misteri dalam masyarakat, yang sangat menarik perhatian karena memuat misteri dan menuntut untuk segera diungkapkan untuk memperoleh kebenaran di balik peristiwa tersebut. Sehingga dapat disimpulkan bahwa pendekatan kualitatif dengan studi kasus merupakan suatu fenomena baik dari suatu program ataupun suatu penerapan kebijakan yang sangat menarik, maka dari itu penulis berminat untuk meneliti judul tersebut dengan menggunakan pendekatan kualitatif dengan metode studi kasus. karena dipandang lebih relevan untuk digunakan didalam mengamati dan menganalisa fenomena-fenomena mengenai implementasi manajemen kepala sekolah dalam mewujudkan sekolah Adiwiyata di SMK Negeri 1 Tembilahan.

Dalam penelitian kualitatif, instrumen utama penelitian adalah peneliti. Artinya, peneliti dalam pengambilan data lebih banyak bergantung kepada diri sendiri. Dengan kata lain, peneliti adalah instrumen utama penelitian. Untuk menunjang instrumen tersebut peneliti juga menggunakan instrumen pendukung untuk mengumpulkan data, yaitu: (1). Observasi, (2). Wawancara, (3). Dokumentasi. Pengujian keabsahan data dapat dilakukan dengan cara perpanjangan pengamatan, peningkatan ketekunan dalam penelitian, triangulasi,diskusi dengan teman sejawat, analisis kasus negatif, dan member check.

\section{HASIL PENELITIAN DAN PEMBAHASAN}

Berdasarkan temuan yang diuraikan. sebelumnya dapat diuraikan beberapa hasil penelitian, yaitu:

1. Perencanaan program Adiwiyata di SMK Negeri 1 Tembilahan, kepala sekolah membuat perencanaan sebagai berikut: (1). Melibatkan semua pihak untuk kesiapan adiwiyata, (2) Melakukan sosialisasi kepada warga sekolah, dan peserta didik (3) Pembentukan tim adiwiyata dengan melibatkan unsur guru dan staf (4) Merancang program kurikulum berbasis lingkungan (5) Merancang program kegiatan lingkungan berbasis partisipatif.

2. Pengorganisasian program Adiwiyata di SMK Negeri 1 Tembilahan. Kepala sekolah SMK Negeri 1 Tembilahan sebagai 
penanggung jawab kegiatan program adiwiyata sangat selektif dalam memilih para guru atau anggota yang masuk kedalam tim adiwiyata. Anggota yang terlibat dalam Tim adiwiyata berasal dari komite sekolah, guru, karyawan tata usaha, dan peserta didik. Kepala sekolah melaksanakan tugas dengan dibantu oleh tim adiwiyata. Tim adiwiyata di ketuai oleh guru yang berkompeten dan memiliki kepedulian yang tinggi terhadap lingkungan. Dalam melaksanakan tugasnya ketua tim adiwiyata di bantu oleh angotaanggota yang bekerja sesuai dengan bidang kegiatannya masing-masing.

3. Pelaksanaan program Adiwiyata di SMK Negeri 1 Tembilahan, Kepala sekolah selaku penanggung jawab penuh terhadap program adiwiyata sekolah melaksanakan tugas dengan baik. Kepala sekolah melaksanakan tugas dengan dibantu oleh komite sekolah, guru, staff dan peserta didik. Dalam melaksanakan tugasnya masing-masing bidang mendapat tugas sesuai dengan bidangnya dan tempatnya masingmasing.

Pelaksanan Program kegiatan adiwiyata meliputi;

1) Kegiatan sosialisasi kepada seluruh warga sekolah dan peserta didik

2) Melakukan kegiatan lingkungan seperti melaksanakan gotong royong di lingkungan sekolah dan di luar lingkungan sekolah,

3) Melaksakan kegiatan pembelajaran yang terintegrasi dengan lingkungan

4) Melaksanakan MOU dengan Bank Sampah

5) Melaksanakan penghijauan dengan melakukan penanaman pohon di area terbuka

6) Melaksanakan pengolahan pupuk kompos

7) Melaksanakan penerapan 3R (Reuse, Reduse dan Recycle)

8) Melaksanakan workshop majelis guru untuk membuat perangkat pembelajaran yang terintegrasi dengan lingkungan.

4. Pengawasan program Adiwiyata di SMK Negeri 1 Tembilahan, dalam mewujudkan sekolah adiwiyata, pengawasan dilakukan oleh masing-masing bidang kegiatan. Dan juga pengawasan dilakukan langsung oleh kepala sekolah dan pihak-pihak terkait seperti unsur dinas pendidikan dan lingkungan hidup kota Tembilahan. Pengawasan dilakukan ketua bidang terhadap bidang-bidang yang melaksanakan program adiwiyata.

\section{SIMPULAN}

Perencanaan Kepala Sekolah dalam mewujudkan sekolah adiwiyata di SMK Negeri 1 Tembilahan, yaitu Kepala Sekolah membuat perencanaan sebagai berikut, melibatkan semua pihak untuk kesiapan adiwiyata, pembentukan tim adiwiyata, membuat jadwal program pembinaan lingkungan, merancang program kegiatan lingkungan, melakukan sosialisasi mengenai program adiwiyata kepada peserta didik dan orang tua di lingkungan sekolah. Kemudian pada pengorganisasian Kepala Sekolah dalam mewujudkan sekolah adiwiyata di SMK Negeri 1 Tembilahan yaitu Kepla Sekolah memilih anggota-anggota tim adiwiyata yang terdiri dari guruguru. Pelaksanaan Kepala 
Sekolah dalam mewujudkan sekolah adiwiyata di SMK Negeri 1 Tembilahan. Dalam melaksanakan tugasnya Kepala Sekolah di bantu oleh anggotaanggota dari tim adiwiyata dan seluruh warga sekolah. dalam melaksanakan tugasnya masingmasing bidang yang ada dalam tim adiwiyata melaksanakan tugasnya dengan baik dan terarah. Pengawasan kegiatan program adiwiyata dilakukan oleh beberapa pihak diantaranya pengawasan dilakukan langsung oleh Kepala Sekolah dan ketua masing-masing bidang kegiatan adiwiyata.

\section{SARAN}

1) Diharapkan agar membuat perencanaan program khusus untuk pelaksanakan kegiatan lingkungan yang melibatkan orang tua peserta didik, agar orang tua juga mengetahui dan ikut terlibat dalam menjaga dan memelihara lingkungan

2) Membuat jadwal kegiatan kemitraan dalam kegiatan adiwiyata, sehingga dapat menyesuaikan mitra mana yang bisa di ajak untuk melakukan kerjasama

3) Dalam pelaksanaan pengawasan kegiatan, kepala sekolah agar selalu melakukan pengawasan kepada bidang kegiatan yang di lihat belum melaksanakan kegiatan dengan baik.

4) Diharapkan kepada pihak SMK Negeri 1 Tembilahan agar selalu melaksanakan program kegiatan adiwiyata dengan baik dan berkelanjutan demi menjaga nama baik sekolah sebagai sekolah adiwiyata.

\section{DAFTAR PUSTAKA}

Fattah Nanang, (1996). Landasan Manajemen Pendidikan, Bandung: PT Remaja Rosda Karya.

George R.Terry dan Leslie W.Rue, (2005). Dasar-dasar Manajemen, Jakarta : PT Bumi Aksara

H.A.R. Tilaar \& Riant Nugroho, (2008). Kebijakan Pendidikan, Yogyakarta: Pustaka Pelajar

Hasbullah, (2014). Kebijakan Pendidikan, Jakarta: PT Rajagrafindo Persada

Hasibuan Malayu S.P, (1990). Manajemen Dasar, Pengetian, dan Masalah, Jakarta: CV. Haji Mas Agung.

Imam Gunawan dan Djum Djum Noor Benty,(2017). Manajemen Pendidikan, Bandung: Alfabeta Muh. Fitrah (2017), Peran Kepala Sekolah Dalam Meningkatkan Mutu Pendidikan. Jurnal Penjaminan Mutu.

Mulyasa. (2017). Manajemen \& Kepemimpinan Kepala Sekolah, Jakarta: PT Bumi Aksara 